\title{
Inward Strategy: An Optimal Solution to Build a Software Industry in Saudi Arabia
}

\author{
Ayman Talib $^{1}$ and Mohammad Malkawi ${ }^{2}$ \\ ${ }^{1}$ Argosy University, Chicago, USA \\ ${ }^{2}$ Middle East University, Amman, Jordan
}

\begin{abstract}
Employing the appropriate strategy was critical in building successful software industry in many developing countries. Through innovative strategies, a number of developing nations were able to create unique software industry models that emerged as strong software exporters at the global level. The main similarity among these strategies was the market orientation; almost all of these strategies were export oriented, software products were produced in the developing countries to satisfy external market demands in the developed world. The need for newer innovative strategies remains a critical success factor for new entrants to the software industry. One of the suggested strategies by the literature was the inward strategy or the focus on the domestic market needs. This paper employs a quantitative approach to identify a possible strategy that Arab countries may adopt to build their own software industry when industry success factors exist in these countries. An analysis of data from published reports and from public databases was used to examine the situation in Saudi Arabia. The goals of this study were, first to pin point the possible strategy that Saudi Arabia may adopt to build its own software industry, second to examine the existence of the software industry success factors in Saudi Arabia. The most significant finding from this study suggested that Saudi Arabia can adopt the inward strategy to build a new software industry model to serve the country's oil and gas industry needs of software. Additionally, this study revealed that Saudi Arabia acquire a number of the software industry success factors like the software demand, the financial resources, and the IT infrastructure while other factors like the quantity of science and technology graduates and the intellectual property and copy right laws are weak and need improvements.
\end{abstract}

Keywords: inward strategy, developing countries, software industry.

\section{Introduction}

The global software industry has become one of the largest growing industries worldwide. The volume of this industry, according to Datamoitor reports, was $\$ 303.8$ billion in 2008 and it is forecast to reach a value of $\$ 457$ billion by the year 2013, an increase of $50.5 \%$ since 2008 .
In today's global economy, businesses around the globe rely on computers in their daily operations. Computers are necessary to run operations in many industries including governments, finance, education, and health. Consequently, software packages and software applications exist commercially to help businesses boost production and maintain steady growth. Fisher and Kenny

Copyright (C) 2011 Ayman Talib and Mohammad Malkawi. This is an open access article distributed under the Creative Commons Attribution License unported 3.0, which permits unrestricted use, distribution, and reproduction in any medium, provided that original work is properly cited. Contact author: Ayman Talib, email: atalib@argosy.edu 
(2000) posit that business software solutions such as management information systems (MIS), enterprise resource planning systems (ERPS), or simply information systems (IS) are vital tools to process and manage huge amounts of information. Therefore, software becomes known as the "brainpower" of today's economy and without these reliable computers' software, business operations and all computer operations become impossible or, close to impossible (Arora, Drev \& Forman, 2009).

In response to the globally increasing demand for software and with the possibility to gain access to the global software markets, many developing countries rushed to take advantage of this opportunity, but unlike their early entrants' counterparts, newcomers were faced with many barriers to access the new software market (Bardhan \& Kroll, 2006). Their major barriers, according to Nicholson \& Sahay (2008), were high competition from earlier exporters, lack of IT skills' levels when compared to earlier exporters, lack of IT infrastructure, and underdeveloped educational systems. These obstacles, on the one hand, stopped some countries and delayed others to participate in the global software activities. On the other hand, other enthusiastic developing countries like Argentina and China derailed their attentions to other routes and shifted their interest from export-oriented strategies toward domestic or inward-market strategies.

Chudnovsky \& López (2005) indicated that for new-entrant nations to build software models, one possible strategy is to adopt the inward-market strategy, look for market niches, and find opportunities with less competition. Among these market niches, the researcher identified language and underresearched areas. The language for example was a market-niche in cases of Spanish, Chinese, or Arabic where the vast majority of these regions speak a language that is considered unique from other parts of the world. In addition to the language, the researcher believed that under-researched areas such as the oil and gas industry, and biotechnology are also among the niches where creating a new software industry model to serve these areas will be possible.

\section{Software Industry and the Inward Strategy}

Inward strategy was fully adopted by Brazilian software companies primarily in developing financial software application for the banking industry, but then expanded to include almost all the business sectors in the country (Gouvea, 2007).

Brazil has the most sophisticated financial system in Latin America with decades of economic stability and high inflation rates. The high performance of the Brazilian financial institutions resulted in these institution demanding sophisticated banking and financial "in-house" software applications (Botelho, Stefanuto, and Veloso, 2005). With the greatest support from the Brazilian government, local software companies were given the opportunities to respond to these demands. This resulted into great benefits to the local industry by acquiring the skills to develop complex systems. Currently, the banking system in Brazil accounts an approximately $30 \%$ of Brazilian investments in IT.

The strategy to develop software in Brazil by focusing on the domestic market was largely driven by the local demands for in-house software products. The supporters of this strategy believed that producing high quality software products for local industries or services- such as the financial sector in Brazil- is a critical step to optimize an industry that can later compete in the global markets (Behren, 2003). Practically, the inward strategy resulted in the creation of thousands of local software companies competing to develop software products. Because of this competition, software firms in Brazil developed distinctive competitive edge technologies and know-how practices, mostly providing software products to the country's leading industry. Throughout the 
optimization process for such products, software firms in Brazil produced financial software solutions that later used in other countries (Gouvea, 2007).

The move to create this local industry required several changes at the governmental as well as other institutional levels. To assist the industry,

Brazilian government created several programs and designed policies specifically targeting the software industry. The science and technology ministry was responsible to design policies; it launched training programs, proposed guidelines and started investment programs to support the software industry. During the same period, several public and private universities and educational institutions created software development centers which later led to the creation of "research poles" in the country (Balbio, 2004).

The software industry in Brazil is dominantly domestic-oriented and has six major areas: finance, electronics, government, information security, telecommunication, and management (Humberto, 2002). Brazil rapidly evolved to one of the largest locally software producing countries. In 2002, Brazilian software industry reached $\$ 7.7$ billion, the seventh largest in the world (Gouvea, 2007).

\section{Software Industry and the Economical Development}

It had been argued that developed countries are the main producers and consumers of software and information services (Chudnovsky \& López, 2005). Major firms in these countries such as Microsoft, SAP, Oracle, and Symantec have been dominating several segments of software production at the world level. Nonetheless, firms in some developing countries were able to penetrate the global software industry; India, Ireland, Brazil, Singapore, Russia and others are among the developing countries that scored significant software exports in the global market (Heeks \& Nicholson, 2004).

Chudnovsky and López (2005) believe, "Software technologies, markets, products and business strategies are constantly evolving." Therefore, chances are always available for new countries to participate in this global industry.

The software industry has been a cornerstone for economic development in many developing countries worldwide (Heeks \& Nicholson, 2004). As a result, governments in these countries began to link their future economical development with the development of their software industry.

Developing countries' interest in the software industry increased even further after the unprecedented success of some developing countries' software models; some countries grew to become one of the world's software export leaders such as India and Ireland (Kambhampati, 2002).

Kapur (2006) pointed out that the first software industry models were export oriented, wherein products were created in the developing countries and then exported back to destinations in the developed world such as the United States, Europe, or Japan. This type of software industry was created in response to external market demands when firms in the developed world, especially the United States and Europe, outsourced portions of their software developments to offshore destinations. In the case of the United States, major firms like Texas Instruments, in seeking cheaper production costs, outsourced substantial portions of its software development to India. Ireland, on the other hand was another target for foreign investors who built software firms in Ireland to satisfy Europe's software needs (Heeks \& Nicholson, 2004). Software business grew spectacularly in these two developing nations; the Indians' software exports grew from $\$ 4.7$ billion in the year 1997-1998 to $\$ 47.8$ billion in 2007-2008, while the Irish 
software industry grew with doubling figures (Nicholson \& Sahay, 2008)..

\section{Software Industry and the Arab World}

Despite the large number of the developing countries that became involved in the global software industry, none of the Arab countries registered any presence in this field. The reasons for this absence are not clearly identified, especially when we examine the list of the developing countries that have entered this field such as India, Ireland, Argentina, and others. In comparison, there are many Arab countries that are financially in a better situation than those that became involved with the software industry. So, what are the real reasons that prevented the Arab countries, at least until now, from participating in this industry? And, is it possible for some Arab countries to develop a successful software industry?

To answer these questions, this research will rely on a developing countries software industry success model developed by Heeks and Nicholson (2004) to analyze the situation in the Arab countries. This study will utilize a quantitative approach to analyze the situation in Saudi Arabia; a wealthy Arab country in the Gulf Cooperation Council (GCC) region.

The goal for this analysis is in two folds: first, to search for the software industry success factors in Saudi Arabia, second, to discuss the possible strategies that Saudis may implement to create a successful software industry.

\section{Software Industry Success Model}

Heeks and Nicholson (2004) in their work of analyzing the software industry success factors in developing countries identified five categories that are critical to create a successful software industry: software demand, people, finance, IT infrastructure, and intellectual property and copyright laws.
- Software demand is crucial for the success of any software model. Demand for software can be of either domestic or external, but in either case, the demand reflects the size of the industry.

- People who become directly or indirectly involved with the industry. In the software industry case, college graduates forms the body of the human capital that carry out most of the software industry tasks.

- Finance is the source of monetary support for the industry. When compared with many other industries like oil and gas, and manufacturing, software industry is still considered the least expensive to create. Despite this, software development requires financial support for $R \& D$, production and distribution.

- The availability of adequate IT infrastructure is also one of the critical requirements to create the software industry. IT infrastructure includes.

- Intellectual property and copyright laws are means of legal protection for the software industry. One of the largest threats that can destroy any software industry is the software piracy. Therefore, the existence of legal forms to protect the industry is essential in the case of the software industry.

This paper proceeds as follows: first a research methodology is described. Second, data collection and data analysis are explained. Third, the rationale to build a software industry in Saudi Arabia is discussed. Finally, the paper ends with a discussion and a conclusion.

\section{Methodology}

A number of published reports and data from public databases were used to analyze the software industry success factors in Saudi Arabia based on Heeks and Nickolson (2002) software industry success model. 
Several variables were included to conduct this analysis. These variables are: software demand, quantity of science and technology graduates, Gross Domestic Production (GDP), patent registration, and IT infrastructure which includes broadband penetration, Internet penetration, mobile phone penetration, and fixed phone penetration.

\section{Data Collection}

The data for the variables in this study were secondary in nature and were collected from the following sources. The researcher collected the data for software demand for the period 2000-2007 from Business Monitor International report. The researcher collected the data for broadband penetration, fixed phone lines and mobile phones for 2000-2007 from the World Bank database and from the International Communication Union database. The researcher collected the data for the quantity of science and technology graduates for 2000-2007 from the UNESCO database. The researcher collected the Gross Domestic Product (GDP) data for the period 2000-2007 from the World Bank database and from the CIA World Factbook. The researcher collected the data for the patent registration for 2000-2007 from the World Intellectual Property Organization (WIPO) database.

\section{Analysis}

A descriptive analysis was used in this study to analyze the software industry success factors in Saudi Arabia. In addition to Saudi Arabia, software industry success factors were analyzed in three software producer countries: India, Ireland, and Argentina. The results of the analyses were used to compare the situation in Saudi Arabia with that in the other three software producers.

\section{Software Demand}

This study presented an eight-year overview of the global IT industry [Table 1].

Table 1. Global Hardware and Software Data, 2000 - 2007

\begin{tabular}{|c|c|c|c|c|}
\hline Year & $\begin{array}{c}\text { Global Software Demand } \\
\text { (B US\$) }\end{array}$ & \% Growth & $\begin{array}{c}\text { Global Hardware Demand } \\
\text { (B US\$) }\end{array}$ & \% Growth \\
\hline 2000 & 128.9 & - & 308 & - \\
\hline 2001 & 135.65 & 5.23 & 301.9 & -1.98 \\
\hline 2002 & 144.96 & 6.86 & 310.45 & 2.83 \\
\hline 2003 & 159.57 & 10.1 & 323.13 & 4.08 \\
\hline 2004 & 180.82 & 13.32 & 340.67 & 5.43 \\
\hline 2005 & 202.97 & 12.24 & 359.73 & 5.6 \\
\hline 2006 & 233.46 & 15.02 & 369.3 & 2.58 \\
\hline 2007 & 268.4 & 14.97 & 390.9 & 5.85 \\
\hline
\end{tabular}

During this period, the global software demand increased by $108 \%$, significantly higher than $27 \%$ increased in the global hardware demand [Figure 1]. In Saudi Arabia the trend was similar; the software demand in Saudi Arabia increased by $98 \%$ compared with a $50 \%$ increase in the hardware demand during the same period, 2000 to 2007 [Figure 2, Table 2]. 
Table 2. Hardware and Software Demand Percentage Growth in Saudi Arabia, 2000 - 2007

\begin{tabular}{|c|c|c|c|c|}
\hline Year & $\begin{array}{c}\text { Hardware Demand } \\
\text { (B US\$) }\end{array}$ & \% Growth & $\begin{array}{c}\text { Software Demand } \\
\text { (B US\$) }\end{array}$ & \% Growth \\
\hline 2000 & 1.296 & & 1.119 & \\
\hline 2001 & 1.316 & 1.54 & 1.214 & 8.49 \\
\hline 2002 & 1.388 & 5.47 & 1.282 & 5.6 \\
\hline 2003 & 1.508 & 8.64 & 1.392 & 8.58 \\
\hline 2004 & 1.6 & 6.1 & 1.6 & 14.94 \\
\hline 2005 & 2 & 25 & 1.72 & 7.5 \\
\hline 2006 & 1.803 & -9.85 & 2.033 & 18.2 \\
\hline 2007 & 1.966 & 9.04 & 2.216 & 9 \\
\hline
\end{tabular}

During the period examined in this study, the data reveals a $10 \%$ annual average increase in the software demand in Saudi Arabia from 2000 to 2007 compared to $6 \%$ annual average increase in the hardware demand in Saudi Arabia in the same period. This change suggests that software demand is a faster growing IT sector in Saudi Arabia.
In addition, a descriptive statistics was conducted for commercial and noncommercial software demand including the oil and gas industry software demand. During the period examined, [Table 3].

Table 3. Descriptive Statistics for Commercial \& Noncommercial Software Demand and Oil \& Gas Industry Software Demand in Saudi Arabia, 2000 To 2007

\begin{tabular}{|l|c|c|}
\hline & $\begin{array}{c}\text { Commercial \& } \\
\text { Noncommercial } \\
\text { Software Demand }\end{array}$ & $\begin{array}{c}\text { Oil \& Gas Industry } \\
\text { Software Demand }\end{array}$ \\
\hline Mean & 600.5 & 971.5 \\
\hline Median & 565 & 931 \\
\hline Standard Deviation & 157.5 & 242.3 \\
\hline Minimum & 415 & 704 \\
\hline Maximum & 836 & 1380 \\
\hline
\end{tabular}

The average for the oil and gas industry software demand was $\$ 971.5$ million; this was $62 \%$ higher than $\$ 600.5$ million, the average of other commercial and noncommercial software demand in Saudi Arabia. Another significant reading from this statistics was that software demand for the oil and gas industry increased by $156 \%$ compared to $101 \%$ increase in other commercial and noncommercial software demand. 


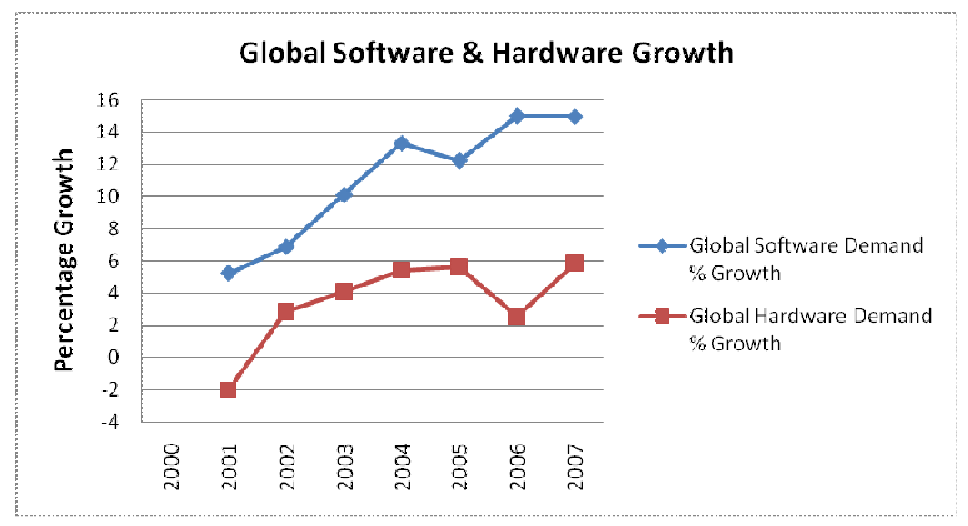

Figure 1: Global Software Demand vs. Global Hardware Demand Percentage Growth, 2000 - 2007.

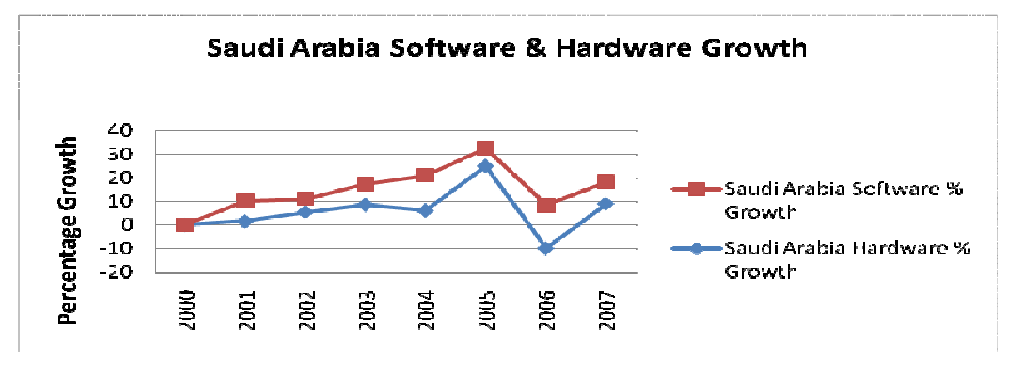

Figure 2: Saudi Arabia Software vs. Saudi Arabia Hardware Percentage Growth, 2000 $-2007$.

Quantity of Science and Technology
Graduates
A descriptive statistics for the quantity of IT and science graduates in Saudi Arabia from 2000 to 2007 were conducted [Table 4].

Table 4. Descriptive Statistics for Quantity of Technology and Science Graduates in Saudi Arabia, India, Ireland, and Argentina, 2000 - 2007

\begin{tabular}{|l|c|c|c|c|}
\hline & Saudi Arabia & India & Ireland & Argentina \\
\hline Mean & 11154.75 & 188954 & 91090.63 & 28134.63 \\
\hline Median & 12626.5 & 204381 & 91669 & 28323 \\
\hline Standard Deviation & 3672.51 & 47324.5 & 7498.69 & 1045.1 \\
\hline Minimum & 4786 & 104259 & 80770 & 26227 \\
\hline Maximum & 15054 & 237430 & 102655 & 29332 \\
\hline
\end{tabular}

During the period examined in the study, Saudi Arabia had an average of 11,154 graduates per year. This average was the lowest compared to India at 188,954, Ireland at 91,090 and Argentina at 28,134, respectively. From this descriptive analysis, 
it was clear that the quantity of science and technology graduates in Saudi Arabia increased for the entire period 2000 to 2007, however, with this increase, the quantity of science and technology graduates in Saudi Arabia remains lower than that in Argentina, India, and Ireland during the same period examined.

\section{Gross Domestic Products (GDP)}

This study presents descriptive statistics for the Saudi Arabia GDP, India GDP, Ireland GDP, and Argentina GDP percentage growth from 2000 to 2007 [Table 5].

Table 5. Descriptive Statistics for GDP Percentage Growth is Saudi Arabia, India, Ireland, and Argentina, 2000 - 2007

\begin{tabular}{|l|c|c|c|c|}
\hline & M & SD & Min & Max \\
\hline Saudi Arabia & 12.13 & 9.48 & -2.88 & 25.65 \\
\hline India & 10.65 & 6.7 & 3.2 & 17.41 \\
\hline Ireland & 12.78 & 8.85 & -0.24 & 27.52 \\
\hline Argentina & 2.06 & 30.46 & -61.08 & 26.89 \\
\hline
\end{tabular}

The descriptive statistics examined the entire period 2000 to 2007. During this period GDP in Saudi Arabia had an average annual growth of $12.13 \%$, the second highest after that in Ireland $12.78 \%$, India $10.65 \%$, and Argentina $2.06 \%$.

There were two significant findings from this statistics. The first significant finding was that GDP in Saudi Arabia increased for the entire period 2000 to 2007 . The second significant finding was that the GDP in Saudi Arabia grew $118 \%$ from $\$ 160$ billion in 2000 to $\$ 352$ billion in 2007 , the second highest after Ireland's GDP growth of 128\%, India's GDP growth of $100 \%$, and Argentina's GDP decline of $-25 \%$.

\section{IT Infrastructure}

IT infrastructure includes broadband penetration, Internet penetration, mobile phone penetration, and fixed phones penetration.

This study presents descriptive statistics for the IT infrastructure in Saudi Arabia from 2000 to 2007.

Table 6. Descriptive Statistics for IT Infrastructure Percentage Growth in Saudi Arabia, 2000 - 2007

\begin{tabular}{|l|c|c|c|c|}
\hline & $\begin{array}{c}\text { Broadband/100 } \\
\text { inhabitants }\end{array}$ & $\begin{array}{c}\text { Mobile Phone/100 } \\
\text { inhabitants }\end{array}$ & $\begin{array}{c}\text { Fixed Phone/100 } \\
\text { inhabitants }\end{array}$ & $\begin{array}{c}\text { Internet User/100 } \\
\text { inhabitants }\end{array}$ \\
\hline Mean & 64.96 & 52.65 & 2.3 & 44.93 \\
\hline Median & 45 & 47 & 2.73 & 35.47 \\
\hline Standard Deviation & 60.31 & 24.56 & 2.1 & 31.21 \\
\hline Minimum & -3.5 & 23.46 & -0.2 & 23.96 \\
\hline Maximum & 150 & 92.66 & 6.09 & 111.68 \\
\hline
\end{tabular}


During the period examined, [Table 6] there were three significant changes in the Saudi Arabian IT infrastructure. The highest change was in the broadband penetration; from 2000 to 2007 the average annual growth of the broadband penetration in Saudi Arabia was $65 \%$. The second highest change was in the annual growth of the mobile phone subscription; during the period 2000 to 2007, the average annual growth of the mobile phone subscription in Saudi Arabia was $53 \%$. The third significant change was in the Internet subscription; during the period examined from 2000 to 2007, the average annual growth in the Internet subscription in Saudi Arabia was 45\%. The weakest change was in the fixed phone subscription, during the period examined, fixed phone subscription average growth was $2 \%$.

During the period examined, the mobile phone subscription and the Internet penetration increased for the entire period 2000 to 2007. Broadband penetration increased moderately for the period 2000 to 2005 , but then significantly increased for the period 2005 to 2007. Actually, mobile phone penetration in Saudi Arabia increased by 200\%; it increased from 38.31 mobile phones per 100 inhabitants in 2004 to 114.74 per 100 inhabitants in 2007. Internet subscription in Saudi Arabia increased by 159\%; it increased from 9.85 subscribers per 100 inhabitants in 2004 to 25.55 subscribers per 100 inhabitants in 2007. Additionally, the study compares broadband penetration in Saudi Arabia to broadband penetration in India, Ireland, and Argentina. During the period examined from 2000 to 2003 broadband penetration in Saudi Arabia was moderately higher than broadband penetration in India, Ireland, and Argentina, but from 2005 to 2007, broadband penetration in Saudi Arabia increased significantly. Actually, broadband penetration during this period increased in Saudi Arabia by $142 \%$ compared to Argentina at $62 \%$, Ireland at $31 \%$, and India at $28 \%$. The study also compares the Internet penetration between Saudi Arabia, Ireland, India, and Argentina. During the period examined, Internet penetration increased in all four countries; the actual percentage increase from 2000 to 2007 was in Saudi Arabia by $159 \%$, this increase was the highest compared to India's 115\%, Ireland's 67\%, and Argentina's 61\%.

\section{Intellectual Property and Copyright Laws}

This study discussed intellectual property and copyright laws in Saudi Arabia from 2000 to 2007. The variables tested were patent applications and patents granted. The descriptive statistics for patent applications in Saudi Arabia, India, Ireland, and Argentina was presented. During the period examined, Saudi Arabia had the lowest annual average of patent applications 160 compared to India's 4,654, Ireland's 2,411, and Argentina's 279. In addition, descriptive statistics for patents granted in Saudi Arabia, India, Ireland, and Argentina from 2000 to 2007 was presented. During the period examined, Saudi Arabia had the lowest annual average, 32 of the patents granted compared to India's 1,117, Ireland's 820, and Argentina's 106.

This study also presented a comparison between patent applications and patents granted in Saudi Arabia from 2000 to 2007.

Table 7. Descriptive Statistics for Patent Applications and Patents Granted in Saudi Arabia, 2000 - 2007

\begin{tabular}{|l|c|c|c|c|}
\hline & M & SD & Min & Max \\
\hline Patent Applications & 160.13 & 104.35 & 52 & 366 \\
\hline Patents Granted & 32 & 29.59 & 0 & 73 \\
\hline
\end{tabular}


During the period examined [Table 7], it shows that the gap between patent applications and patents granted in Saudi Arabia continued to grow overtime. From 2000 to 2007, for example, the annual average of patent applications exceeded four times the annual average of patents granted. A linear graph also compared patents granted in Saudi Arabia with patents granted in India, Ireland, and Argentina. During the period examined, Saudi Arabia showed the lowest number of patents granted for the entire period from 2000 to 2007. For example, Saudi Arabia's annual average of patents granted was $2.86 \%$ of the annual average of India patents granted, $3.90 \%$ of the annual average of Ireland patents granted, and $30 \%$ of Argentina patents granted. This study also examined whether the software demand for the oil and gas industry in Saudi Arabia represents a distinctive success factor for a new software industry model.

\section{Findings}

This study revealed several important findings in relation to the subject of creating a successful software industry in Saudi Arabia; these findings are summarized as follows:

1. In earlier software industry models, software demand represented one of the critical success factors that enabled countries like India, Ireland, and Argentina to build successful software industries. The level of software demand will continue to be the driver for the creation of newer software industry models in developing countries like Saudi Arabia. The findings from this study revealed that software demand in Saudi Arabia is significantly growing, and when compared to other IT sectors, software demand in Saudi Arabia was the fastest growing.
2. The existence of sufficient quantities of technology and science graduates represents the IT human capital that is necessary for the software development and production. Saudi Arabia, unlike the other three countries examined in this study, lacks the sufficient quantities of technology and science graduates. This inefficiency in the number of graduates affects Saudi Arabia's ability to create a software industry. Therefore, major improvements are necessary in the Saudi Arabian education system that will lead to the production of more technology and science graduates.

3. The findings from the current study suggest that the growth in the Saudi Arabian GDP is significant. And when compared to the other three countries included in this study, the growth in the Saudi Arabian GDP was in the second place after Ireland. Therefore, these findings indicate that there are sufficient financial resources in Saudi Arabia that can aid the creation of a new software industry.

4. The findings from the current study revealed that IT infrastructure in Saudi Arabia witnessed major improvements, especially in broadband penetration, mobile phone penetration, and Internet penetration. And when compared to the other three countries included in this study, Saudi Arabian IT infrastructure proved to be either in the first or the second place. Therefore, these findings indicate that Saudi Arabia obtain another software industry success factor which is the IT infrastructure.

5. The findings from the current study revealed that the change in enforcing the copyright and intellectual property protection laws was weak. These findings suggest that Saudi Arabia needs to improve the intellectual property and copyright protection laws as a step 
toward providing this important success factor for the software industry.

6. The findings from the current research revealed that software demand for the oil and gas industry is the fastest growing when compared to software demand for other commercial and noncommercial software demand. Therefore, based on these findings, software demand for the oil and gas industry may represent a market niche for a new software industry model in Saudi Arabia.

\section{The Rationale to Build a New Software Industry Model in Saudi Arabia}

Economic development is the fundamental objective for policymakers in both developed and developing countries (Engelbrecht, 2005; Hall, 2007). In the most productive and growing economies in the developed countries, industrial sectors develop innovative capabilities through enormous investments in technology (usage and production) to sustain the economic growth with the continuous evolving and dynamic global competition environment (Akman \& Yilmaz, 2008; Ägerfalk, et al., 2007). Similarly, developing countries have become firmly convinced that investment in IT will bring about potential capabilities of economic development such as technological innovation, effective usage, and creation of IT products and services (Akman \& Yilmaz, 2008). In addition, countries that became involved in IT production witnessed unprecedented movements of job creation opportunities, diffusion of IT best practices among wide ranges of society sectors, and transformation of the technology knowledge to different levels of economical sectors.

In a recent study that measured the impacts of IT investments (including commercial software) in eight Latin American countries (Argentina, Brazil, Colombia, Chile, Costa Rica, Mexico, Peru and Vanezuela), researchers Ania \& Mejía (2007), Chudnovsky \& López (2005), Nicholson \&
Sahay (2008) found that economic situations significantly improved in countries that invested in commercial software development. More specifically, the researchers found that in countries that invested in software sectors, GDP increased by an average of $1.883 \%$ for every $10 \%$ increase in the software development investments. In addition, the researchers were able to measure the positive impact of investments on software production on the employment opportunities in these countries. For example, when Brazil invested US $\$ 16.4$ billion in the IT sector in 2006 , an additional 102,200 employees were added to the IT industry, a $12.3 \%$ increase to the 2002 total employees (Nicholson \& Sahay, 2008). In Mexico, too, the total number of employees increased by 80,000 people in 2006 as a result of additional investments in the IT sector (Ania \& Mejía, 2007).

It can be concluded from the above discussion that as an IT producing sector, a software industry can act as a driving force for potential economic growth in a developing country like Saudi Arabia for two reasons. First, as an independent industry, software has a high return on investment, making it a profitable industry. Second, as a technology provider, software can aid other economical sectors (industrial and nonindustrial, governmental and nongovernmental) to grow by integrating technological products and services within these sectors.

\section{Software Demand in Saudi Arabia}

Saudi Arabia IT spending reached US \$3.4 billion in 2008. It is forecast to reach US $\$ 5.6$ billion by 2013 an increase by 39\% with software and services accounting for the higher spending amongst the other IT sectors (Business Monitor International, 2009).

Al-Gahtani (2003) claims that software demand in Saudi Arabia is driven by vigorous industrial and economic development in major areas such as oil and gas, financial, telecom, health, power, government and education; with the oil and gas industry 
representing the major software consumer in the kingdom. Choudhury \& Al-Sahlawi (2000) claim that oil and gas industry consumes about $20 \%$ of the total software sales in Saudi Arabia. On the other hand, many firms and organizations in Saudi Arabia recognize the impact of technology adaptation on posting their productivity and improving their performance. As a result, larger numbers of firms in the Saudi kingdom are in the process of transferring from manual into fully automated business processes relying in the first place on technology and software solutions (Choudhury \& Al-Sahlawi, 2000). In addition, software demand is growing within the government in Saudi Arabia to satisfy the increasing interest in e-government and eadministration. Indeed, this movement toward e-government required the kingdom to place a special section in the state budget (Dibooglu \& Aleisa, 2004). Beside the industry and the government, software demand is increasing in Saudi Arabia from the expansive use of PCs and the Internet in personal computing. For example, the number of computer sales reached US $\$ 1.6$ billion in 2008 with PC penetration of $23 \%$, an increasing trend that is expected to continue for the next five years (Business Monitor International, 2009).

\section{Computer Software as a Strategic Industry}

Looney (1997) stated that high oil revenues formalized main sources of income to many Middle Eastern countries including Saudi Arabia. Dibooglu \& Aleisa (2004) explain that the petroleum sector accounts for more than $80 \%$ of the total Saudi Arabian budget revenues, $45 \%$ of GDP and nearly $90 \%$ of total exporting. In addition, the CIA World Factbook (2008) data shows that Saudi Arabia accounts for 266.8 billion bbl of approved reserved oil, with an estimate oil production of $9.2 \mathrm{million} \mathrm{bbl} /$ day out of which 8.2 million bbl/day is for export.

Despite the large revenues that Saudi Arabia generates annually from oil sales, some researchers argue that the reliance on oil and gas become questionable in times when oil prices decline or become unstable (Dibooglu \& Aleisa, 2004). This same argument made other researchers believe that after the 1970's oil crisis, Saudi Arabia started to diversify its industry and began to "de-link" its economy from full reliance on the oil and gas industry (Choudhury \& Al-Sahlawi, 2000). This new era of the Saudi's economy witnessed the rise of new industries like steel, food, textile, appliances, and machinery (Looney, 1988). In addition to these industries, Saudi Arabia may consider the software industry as a major production industry in the kingdom for the following reasons:

1. Software is a relatively low-investment industry compared to many other industries.

2. Software as a production industry has a high return on investment.

3. Software is an environmentally friendly industry.

4. Software is a high-growth global industry.

5. The software industry can serve the high domestic market demands especially the demands from the oil and gas industry.

\section{Discussion and Conclusion}

The first goal for this research was to indentify the software industry success factors in Saudi Arabia. This was achieved by analyzing the situation in Saudi Arabia against the software industry success model for Heeks and Nicholson (2004). In this model, the researchers claim that the existence of the software industry success factors is critical for any country to create a successful software industry. The industry success factors according to the success model are: the software demand, quantity of science and technology graduates, Gross Domestic Production (GDP), patent registration, and IT infrastructure. The 
analysis of the previous variables was derived from a number of published reports about the software industry in developing countries and from public databases that contain information about the similar subject in this study.

The analysis of the software demand in Saudi Arabia was conducted by comparing the growth trend in the software demand in Saudi Arabia with the global software demand growth. This analysis revealed that globally the software demand grew steadily and that growth was significantly faster than the growth in other IT sectors like the hardware. Similarly, the software demand in Saudi Arabia significantly grew at a rate faster than other IT sectors in the country. The trend of the software demand growth in Saudi Arabia if continues at the same or faster rate represents a positive signal for the proposed model.

The quantity of the science and technology graduates ranks the second important factor in Heeks and Nicholson model. This study analyzed the quantity of science and technology graduates in Saudi Arabia; this analysis only considered the graduates with direct relation with the software industry. In this analysis, we compared the number of graduates in Saudi Arabia with the number of graduates in three software producing countries: India, Ireland and Argentina. The analysis revealed that the average of the science and technology graduates in Saudi Arabia remained below the average of the graduates in the other three countries included in the analysis. This result signals a weak link in the software industry success factors. Also this result alarms the decision makers in Saudi Arabia about the significance of the problem. The third important factor is the existence of financial resources to support the industry. We analyzed this factor by comparing the GDP growth in Saudi Arabia with that in India, Ireland, and Argentina. The analysis revealed that the GDP significantly grew in Saudi Arabia for the entire period covered in this study; this growth represents a healthy economical situation in the country which consequently adds another strong factor to the proposed model.

The fourth important factor is the existence of intellectual property and copy right laws to protect the industry. Although the analysis of the rate of piracy or the registration of the IP addresses will be more appropriate to detect the level of property protection in Saudi Arabia, the lack of published data about this sensitive information forced the authors of this paper to analyze this issue with the existence data from the public sources. The justification to go this route may be explained by the fact that if the intellectual property and copyright laws activity are high in a country, then the software products will not be excluded from such protections. However, future studies may conduct further analysis using data from Saudi Arabian sources that specifically contains information about intellectual property for software and other IT sectors.

The analysis of the intellectual property and copyright laws in Saudi Arabia was conducted by comparing the situation in Saudi Arabia with that in India, Ireland and Argentina. It was clear from the analysis that the intellectual property and copyright laws activities were the lowest in Saudi Arabia compared to the other countries included in the study. This result indicates another weak link in the software industry success factors for the proposed model.

The last factor covered in this study was the IT infrastructure. This factor was analyzed by first examining the growth of the IT infrastructure in Saudi Arabia, second by comparing the growth rate of the IT infrastructure in Saudi Arabia with that in India, Ireland and Argentina. The analysis revealed a significance growth in the IT infrastructure in Saudi Arabia over the entire period examined in this study. In addition, in comparison with the other three countries, IT infrastructure grew at a higher rate in Saudi Arabia. These findings indicate that Saudi Arabia acquires another strong success 
factor that can add a significant strength to the proposed model in Saudi Arabia.

The second goal for this study was to identify the best fit strategy to develop a software industry in Saudi Arabia.

Late comers like Brazil adopted the inward strategy to develop software industry model that primarily served the local market needs. Brazil software model targeted the country's strongest business sector-the financial sector- that demanded complex software applications to run such sophisticated systems. The Brazilian model then expanded to cover other major business and private sectors in the country: telecommunication, business management, large-scale customer management system, government agencies, and other private sectors. This specialization resulted in the development of specific technology and expertise that resulted in elevating the quality of Brazilian software products; in the financial sector for example, Brazilian software companies produced premium software packages that were later sold in global markets.

Saudi Arabia can follow the same strategy as Brazil in adopting the inward strategy. The domestic demands in Saudi Arabia are similar to those in Brazil. The largest industrial sector in Saudi Arabia is the oil and gas industry. The software demand from this sector represented $20 \%$ of the total software demand of $\$ 3.4$ billion in 2008 and it is expected to increase. A software model in Saudi Arabia (see Figure 3 below) may first target the oil and gas industry sector similar to the Brazilian model that targeted the strong financial sector in the country. The focus on this sector will develop the knowledge and the expertise that are necessary to develop premium solution for this sector. Once reach the optimization stage, the industry will then expand to cover other business and governmental sectors.

Adopting the inward strategy in Saudi Arabia is critical to build the software industry in the country. As a late comer to the industry, Saudi Arabia needs to focus on its higher software demand sector; the oil and gas sector. As a result, the software model in Saudi Arabia will initially deploy all necessary resources to optimize software solutions for the oil and gas sector. This specialization will form the right nucleus for the software industry, from which the model will expand to cover the rest of the sectors in the country.

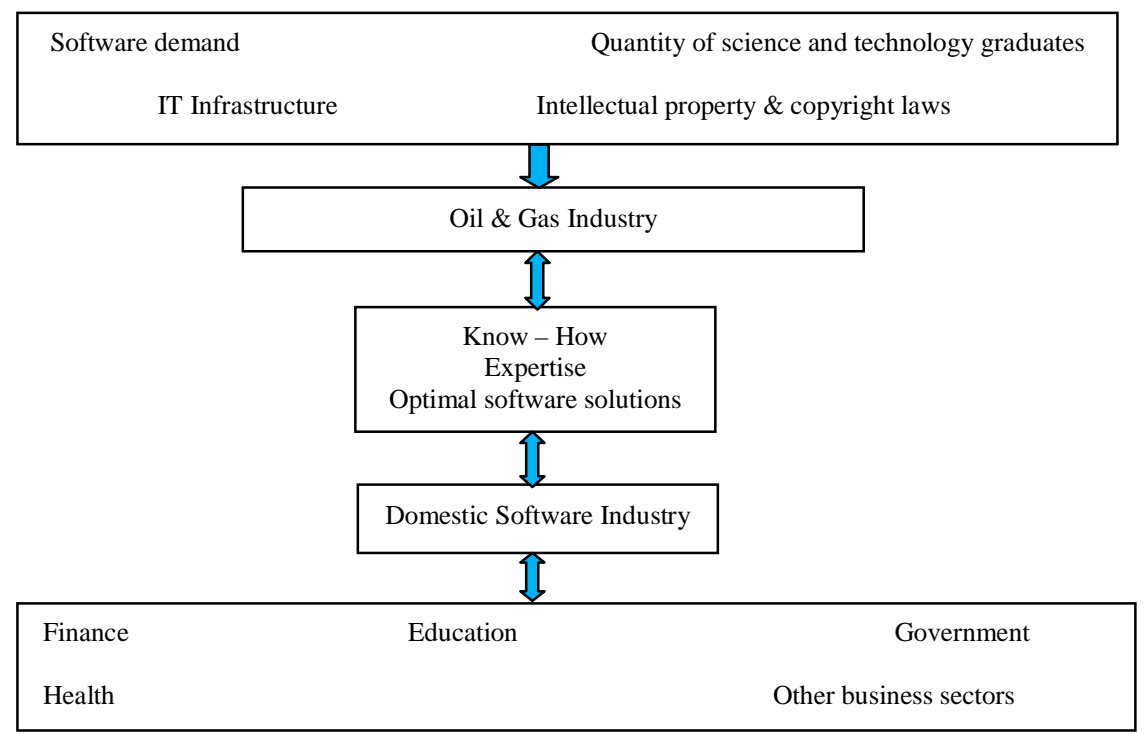

Figure 3. Software Industry Model in Saudi Arabia 
From the above proposed model, it is obvious that software industry success factors represent the initial step to start the industry. Having studied the Saudi Arabian context let us draw some conclusions and implications about creating the software industry in Saudi Arabia. First, let us consider the software industry success factors that we analyzed in this study and ask these two fundamental questions: does Saudi Arabia acquire any of the software industry success factors? And, if so, what is the level of strength for these individual factors?

Table A below summarizes the software industry factors, their weaknesses and strengths in Saudi Arabia.

Table A: Summary of Saudi Arabian Software Industry Success Factors; Strength and Weaknesses

\begin{tabular}{|l|l|l|}
\hline Factor & \multicolumn{1}{|c|}{ Dimension } \\
\hline Software demand & $\begin{array}{l}\text { Strong domestic software } \\
\text { demand from the oil and gas } \\
\text { industry and from other } \\
\text { business sectors }\end{array}$ & \\
\hline $\begin{array}{l}\text { Quantity of science and } \\
\text { technology graduates }\end{array}$ & Strong broadband penetration & $\begin{array}{l}\text { Weak average graduates in the } \\
\text { science and technology fields }\end{array}$ \\
\hline Intellectual property & Strong Internet penetration & Weak intellectual property and \\
\hline Broadband penetration & $\begin{array}{l}\text { Strong laws activities } \\
\text { penetration mobile phone }\end{array}$ & \\
\hline Internet penetration & \multicolumn{2}{|c|}{} \\
\hline Mobile phone penetration &
\end{tabular}

The results of the analysis in this study revealed that Saudi Arabia acquires the software industry success factors, but with different strength levels. The table above identifies domestic software demand and IT infrastructure as strong software success factors and quantity of science and technology graduates, and Intellectual property and copyright laws as weak software industry factors. These results suggest that people who are interested in creating the software industry in Saudi Arabia need to improve the weak areas by allocating all necessary resources and at the same time sustain the improvement of the strong factors. To improve the weak production of the science and technology graduates, decision makers in Saudi Arabia need to create special programs and research centers in the educational institutions and universities. The goal of these programs is to produce the graduates who will later become the software industry work force. The other weak factor according to our analysis was the intellectual property and copyright laws activities in the country, to improve this factor, decision makers and law makers need 
to construct the laws and the policies to protect this new industry.

\section{References}

Ägerfalk, P. J., Fitzgerald, B., Holmstrom, H. \& Conchúir, E. Ö. (2007). 'Global Software Development: How Real are the Benefits?,' Engineers Journal, 61, 353-356. Retrieved March 5, 2009, from EBSC囵 database.

Akman, G. \& Yilmaz, C. (2008). "Innovative Capability, Innovation Strategy and Market ?rientation: An Empirical Analysis in Turkish Software Industry," International Journal of Innovation Management, 12, 69-111. Retrieved March 7, 2009, from EBSC? database.

Al-Gahtani, S. (2003). "Computer Technology Adoption in Saudi Arabia: Correlates of Perceived Innovation Attributes," Information Technology for Development, 10, 57. Retrieved April 20, 2009, from EBSC? database.

Ania, I. \& Mejía, M. (2007). "Considering the Growth of the Software Services Industry in Mexico," Information Technology for Development, 13, 269-291. Retrieved March 12, 2009, from EBSC? database.

Arora, A., Drev, M. \& Forman, C. (2009). "Economic and Business Dimensions: TheExtent of Globalization of Software Innovation," Communications of the ACM, 52, 20-22. Retrieved March 15, 2009, from EBSC? database.

Balbio, Marcelo (2004). 'Projeto do Porto Digital: Um Restart na Historia,' ? Globo, January 12, Caderno de Informatica, p.1 (2).

Behrens, Alfredo (2003). 'Brazilian Software: The Quest for an Export ?riented Business Strategy,' DRC Working Papers, No. 21 (Sao Paulo: FECAP).

Botelho, Antonio, Giancarlo Stefanuto \& Francisco Veloso (2005). "The Brazilian Software Industry," In Ashish Arora and
Alfonso Gambardella, eds., From Underdogs to Tigers (New York: ?xford University Press), pp. 99-130.

Bardhan, A. D. \& Kroll, C. (2006). "Competitiveness and an Emerging Sector: The Russian Software Industry and its Global Linkages," Industry \& Innovation, 13, 69-95. Retrieved March 23, 2009, from EBSC? database.

Business monitor international report. (2009). Retrieved March 13, 2009, from http://www.businessmonitor.com/saudi_ara bia_information_technology_report.html

Choudhury, M. A. \& Al-Sahlawi, M. (2000). "?il and Non-oil Sectors in the Saudi Arabian Economy," OPEC Review: Energy Economics \& Related Issues, 24, 235. Retrieved April 11, 2009, from EBSC? database.

Chudnovsky, D. \& López, A. (2005). The Software and Information Services Sector in Argentina: The Pros and Cons of an Inwardoriented Development Strategy," Information Technology for Development, 11, 59-75. Retrieved January 11, 2009, from EBSC? database.

CIA World Factbook database. (2008). Retrieved April 5, 2009, from https://www.cia.gov/library/publications/t he-world-factbook

Dibooglu, S. \& Aleisa, E. (2004). "?il Prices, Terms of Trade Shocks, and Macroeconomic Fluctuations in Saudi Arabia," Contemporary Economic Policy, 22, 50-62. Retrieved ?ctober 20, 2008, from EBSC? database.

Engelbrecht, H. (2005). "ICT Research, the New Economy and the Evolving Discipline of Economics: Back to the Future?," Information Society, 21, 317-320. Retrieved April 10, 2009, from EBSC? database.

Fisher, B. \& Kenny, R. (2000). "Introducing a Business Information System into an Engineering Company," Information Knowledge Systems Management, 2, 207. 
Retrieved April, 3, 2009, from EBSCO database.

Gouvea, Raul (1991). 'El papel catalitico del gobierno Brasileno en la exportacion de tecnologia, produtos primarios, semieleborados yelaborados,' Estudios de Economia, 18(2), pp. 267-287.

Hall, J. L. (2007). "Informing State Economic Development Policy in the New Economy: A Theoretical Foundation and Empirical Examination of State Innovation in the United States," Public Administration Review, 67, 630-645. Retrieved March 26, 2009, from EBSCO database.

Heeks, R. (2002). "Information Systems and Developing Countries: Failure, Success and Local Improvisations," Information Society, 18, 101-112. Retrieved March 2, 2009, from EBSCO database.

Heeks, R. \& Nicholson, B. (2004). "Software Export Success Factors and Strategies in 'Follower' Nations," Competition \& Change, 8, 267-303. Retrieved March 24, 2009, from EBSCO database.

Humberto, L. (2002). 'Competitiveness of IT Services,' (São Paulo: T-Systems do Brasil).

International Communication Union database. (n.d.). Retrieved March 17, 2009, from http://www.itu.int/ITUD/icteye/Indicators/Indicators.aspx

Kapur, S. (2006). “From Underdogs to Tigers:
The Rise and Growth of the Software Industry in Brazil, China, India, Ireland and Israel," Economic Journal, 116, 156-157. Retrieved March 9, 2009, from EBSCO database.

Looney, R. E. (1988). "The Impact of Technology Transfer on the Structure of the Saudi Arabian Labor Force," Journal of Economic Issues, 22, 485. Retrieved March 22, 2009, from EBSCO database.

Looney, R. E. (1997). “Saudi Arabia's Evolving Growth Mechanism: Patterns Derived from Cointegration Analysis," OPEC Review: Energy Economics \& Related Issues, 21, 209221. Retrieved April 28, 2009, from EBSCO database.

Nicholson, B. \& Sahay, S. (2008). "Human Resource Development Policy in the Context of Software Exports: Case Evidence from Costa Rica," Progress in Development Studies, 8, 163-176. Retrieved April 25, 2009, from EBSCO database.

UNISCO database. (n.d.) Retrieved February 9, 2009, from http://portal.unesco.org/education

World Bank database. (n.d.). Retrieved March 12, 2009, from http://www.worldbank.org

World Intellectual Property Organization (WIPO) database. (n.d.). Retrieved March 22, 2009, from http://www.wipo.int/portal/index.html 